sclerosis in the lateral columns of the spinal cord, disseminated sclerosis, etc.), but that it is just possible that in some rare cases of organic nervous disease (for instance, some cases of early disseminated sclerosis) the organic changes may give rise to the phenomena of increased tendon reflexes, etc, merely by inducing the above.mentioned (h ypothetical) functional cerebral change.

To illustrate mp meaning further, I shall now allude to the analogous question of the nature of functional nervous vomiting. In an article contributed to Brain in $1904^{3} \mathrm{I}$ endeavoured to show that functional nervous vomiting, like the hemianaesthesia, palsies, and spasms of hysteria, must be regarded as due to an abnormal state of the brain (cerebral cortex), and is just as much a $85 \mathrm{~m}$ ptom of functional brain disease as the vomiting in cases of cerebral tumour is of organic brain disease. We know that violent vomiting is frequently a result of organic disease (tumours, etc) and Injuries (involving concussion) of the brain, and that vomiting of cerebral orlgin often occurs in the absence of any gross change in the brain (lor instance, in simple concussion and in ordinary sea-sickness, and from toxic causes acling on the cerebral cortex, such as uraemia, and from the inhalation of chloroform and ether), and may even be due to purely psychical causeg-such as idess connected with disagreeable smells and sights, the view of blood and surgical operatlong, and various mental emotions. Now, patients with functional nervous vomiting mostly exhibi characteristic slgns of hysteria, and it is generally recog. nized, I believe, that the main \&ymptoms of hysteris, such as hysterical hemianaesthesia, hysterical monoplegias, and hysterical spasms, owing to their characteristic distributions, etc, are of cerebral cortical origin, just as much so as the mental sy mptoms of hysteria are. I believe, therefore, that in vomiting of functional nervous origin the main. site of the disturbance in the nervons system is most probably likewise in the brain (cerebral cortex), and, practically speaking, I regard the vomiting of organic brain disease as an Imitation of that due to functional brain dlsease (hysteria). The vomiting due to functional disease may in rare cases-true faecal vomiting of functional nervous origin-be more violent than any vomiting caused by organlc disease. With regard to the violence of the symptoms in such exceptlonal cases, I wrote In the paper above relerred to:

"Why the romiting in functional brain 'disease should be sometimes actually more violent and severe (faecal vomiting) than it is in organfc cerebral disease (faecs ( vomiting practithan is is organic cerebral disease (laecsl vomiting practically never occurs in organic brain disease) I cannot underin a more pronounoed form in a brain without any gross organio disease than it can in a brain the finer mechanism of which has already been impaired by severe organic disease, such as cerebral tumour. In connexion with such a suppcsition one may remember that a delusion is apt to be less stable (and not so well organized) in a general paralytic, whose brain ts the site of grave orgenic disease than in a with chronle paranoia, whose brain, could it be $\in$ xamined, would probably show no obvious organic changes."

In conclusion, I maintain that in functional nervous vomiting we probably have to deal with a pecullar functional change in the brain (cortex), analogous to the cerebral condition that produces the exaggerated tendon reflexes and "trepldation" of functional nervous origin, and which, like it, may be excited or modified by emotional factors, and is anslogous to certain states induced by toxaemias - such as uraemis. The symptoms produced by these abnormal functional states may equal or even exceed those produced by organic disease.

RE FERENCES.

1 Spontaneous Symmetrical Ecchymoses of the Eyelids and Conjunctivae, with Extraordinary Exaggeration of all the Tendon Reflexes preceding Fatal Uraemic coma, Brilish Journal of Dermatology, september, 1906, p. 323. 2. Trophic Disorder of the Feet, British Jeurnal of Deristalsis in 1904, p. 170.

THE Deutsche medizinische Wochenschrift announces, on the authority of the German Ambassador at Tokyo, that foreign doctors who wish to obtain the right to practise their profession in Japan may pass the necessary examination in English, French, or German, or may employ the services of an interpreter. Moreover, the interval which in the case of Japanese candidates must elapse between the two parts of the medical examination $m i y$ be dispensed with in the case of foreigners holding a medical diploma.

\title{
TYPHOID CARRIERS.
}

BY

ALEX, LEDINGHAM, M.D , M A., D.P.H., MEDICAL OFFICER OF HEALTH

DURING the past two yesirs the important question of "chronic typhold carrlers" has received a large amoun of attention at the hands of German hygienists and bacteriologists.

Hitherto the importance of the subject from the point of view of public health has been insufficiently realized in this country. Recently an American worker has recorded one very interesting case to which reference wlll be made later. It is not proposed here to discues in detail the various published cases, which alter all present so mavy points of similarity. It will suffice to refer briefly to the more important articles, after which we shall record our own experiences in this matter.

German Experiences.

For a large part of our knowledge of the subject we are indebted to bygienists in Strassburg. The now classical case of the strassburg femsle baker was described by Kayser in 1906. The facts of the case were brif fly these: It was observed that practlcally every rew 6 mployee in the bakery became sooner or later serlouely ill with intestinal typhoid-like symptoms. In two persons the disease proved fatal. The faeces of the woman who owned the bakery and who had had typhoid fever ten years previously, were found to contain typhoid bacilll in large numbers. Her serum also agglutinated the Bacillus typhosus up to 1 in 100. Kayser (1906) was also able to 18olate another carrier in the person of a female engaged in the milk trade. She was apparently responsible for a small typhoid epidemic due to infected milk, in which 1'? cases were involved, with two fatalities.

Further, several epidemics in a household were traced to a female who had had typhold fever complicated with jaundice thirty years previously. In all, twelve carriers wers found ( 9 female and 3 male). The ratio ( 3 to 1 ) probably also expresses the Incidence of gall-stone disease in the female and male respectively. Klinger. (1908), in an examination of the stools of 482 cases of typhoid fever, found that 27 , or 13.1 per cent, harboured the bacilli; of these 87 , however, 8 only continued to halbour the bacllli longer than six weeks alter the temperature had become normal, so that altogether 1.7 per cent. became chronic carriers. These cases were followed up for vanying periods up to eleven months. Klinger places in a separate group a series of 11 cares (6 male and 5 female), who were found to pass typhold bacilli in the etools for a short tlme only. These people had not had typhoid fever, but had been closely associated with trphoid patients. These temporary harbourfro of the bacillus, or "acute typhoid carriere," he does not consider to be relatively so dangerous as the chronic or persistent carritrs. It seems unjustifiable to dogmatize on tbls point, as the passage of bacllli in the stools probably takes place intermittent]y, and repeated examination at intervals would be required to setile this questicn.

Lunatic asylums appear to yield a considerable number of the cases recorded; and, as our expt rlence has been obtalned with material from this source, it mas be well to summarize the chief evidence.

In the course of an investigation into the canses leading. to a succession of typhoid epidemics which had occurred in an asslum containing 250 patients, Nieter and Liefmann (1906) were able to isolate eeven ty phoid carriers. They had commenced with an examination of the stools of patients who had recovered from typhoid fever, but none of these were found to harbour the typhoid bacillus. A certain patient, horever, happened to be suffering from dysentery, and in her stools typhcid bacllli were found, along with dysentery bacilli of type "Flexner." In the faeces of another patient who had the churacteristic symptoms of dyzentery, typhoid bacllli were tound, but no dysentery bacilli. Alter death typhold bacilli were found, not only in the Intestine, but also in the bile. Tre blood of this patient also agglutinated $B$. tys hoi us up to 
1 in 50, and the $B$. dysenteriae (Flexner) up to 1 in 100 . Old typhoid cicatrices were found in the small intestine, while the large intestine showed chronic catarrb.

Probably the infection of these dysentery cases with the Bacillus typhosus was due to the fact that, owing to lack of room, the typhold and dysentery cases were not lsolated in separate buildings. The transference of in fection from one patient to another is readily concelvable when the filthy habits of many. of these cases are remembered.

Farther notes on the conditions prevalling in this asylum were recently recorded by Nieter (1907). The agylum contained altogether about 900 females, and the prevlous 7 cases had been discovered in one bullding containing 250 female inmates. In addition to these 7. cases, 4 athers were found, and it was hoped that with the lsolation of these no more outbreaks would arise. However, during the course of December, 1906, and January, 1907, 3 cases of typhoid fever occurred among emale attendants. In the room in which these attendants had served was found another carrier. This female harboured the paratyphoid bacillus (type B) in addition to the Bacillus typhosus.

Four or five months later sn ontbreak occurred in enother department. This led to the discovery of yet another chronic carrier who had had typhoid fever two years previously. Altogether in this asylum 13 cases were brought to light.

The experience of Friedel (1907) is especially interesting, as the outbreaks occurring in a similar institution were clearly traced by him to an imbecile patient who did work in the kitchen department. This person had never onffered from typhoid fever. It is important to note that her work in the kitchen consisted chlefly in the pre paration of varlons salads.

In an asylum at Hördt as described by Klinger, two carriers were found and isolated. It happened that in the typhoid-infected bnilding there was a washerwoman who had suffered from typhoid fever one year previously. Her stools were examined three times, and found to be tree of typhoid bacllli (February and Mirch, 1905). However, in September, 1905, other cases broke out in her department, and she was now found to be a carrier. Her serum agglatinated the Bacillus typhosus up to 1 in 1,000 .

Other carrier cases isolated in asslnms at Saargemünd and Klingemünster are mentloned by Nieter. The American case described recent'y by Sorer (1907) of New York concerned a female cook, in apparently perfect beslth, who, so far as her history conld be traced, had in the course of five years been responsible for the occurmence of typhoid epidemics in seven different households. Her stools we:e found to contain typhoid bacllli in large numbers, and her serum gave a positive Widal reaction.

Cause of the Preasex t Inverstigation.

A certain lunatic asplum in Scotland, containing at the present time 92 male and 53 female patients, 8 male and 6 female attendants, and 4 female servants, has since 1893 been visited by a succession of small outbreaks of typhoid fever. Similar outbreaks have occurred during the same time in a smaller detached institution situated about five minutes' walk from the maln building. Female patlents only, to the number of 32 ; occupy at present this smaller aeylum. Prior to the adoption of the Notlfication Act in 1891 no authentic records of typhoid fever in this institution are avallable.

Thlrty-one cases in all have 'occurred, and 24 of these have been females. Nine cases have proved fatal, giving a ta'ality rate of 29 per cent. Included in the accompanying table are 4 cases among the attendant staff ( 3 female and 1 male). It will be observed from the table that the cases occurred at no special time of the year, but that in any one year the notlfied cases followed each other as a rule very closely. Daring 1894, 1898, 1902, and 1905, no cases were notified.

As might be expected, the mysterious cropping up of typhold cases has been a source of great anxiety to the authorities, who have done everything in thelr power to make the sanitary arrangements of the institution as complete as possible. Repeated analyses of the water supply, both chemically and bacteriologically, have thrown no light on the etlology of the outbreaks. The sewage is conveyed direct to the sea. The dairy arrangements are in excellent order. The same water supply is enjoyed by
Table Showing the Incidence of Typhoid Fover in Successive Years since 1893. when the First Case was Notified.

\begin{tabular}{c|c|c|c|c}
\hline Year. & $\begin{array}{c}\text { Total } \\
\text { Number } \\
\text { of } \\
\text { Cases. }\end{array}$ & $\begin{array}{c}\text { Month of } \\
\text { Notification. }\end{array}$ & $\begin{array}{c}\text { Main } \\
\text { Asylum. }\end{array}$ & $\begin{array}{c}\text { Small } \\
\text { Asylum. }\end{array}$ \\
\hline 1893 & 2 & March, July & 2 & 0 \\
1894 & 0 & - & 0 & 0 \\
1896 & 6 & July (2), August (3), December (1) & 1 & 5 \\
1896 & 2 & April, May & 2 & 0 \\
1897 & 1 & November & 0 & 1 \\
1898 & 0 & - & 0 & 0 \\
1899 & 4 & August (1), November (3) & 4 & 0 \\
1900 & 3 & January, June, August & 1 & 2 \\
1901 & 2 & February, May & 2 & 0 \\
1902 & 0 & - & 0 & 0 \\
1903 & 4 & February, March, April, October & 4 & 0 \\
1804 & 3 & June, July, August & 3 & 0 \\
1905 & 0 & - & 0 & 0 \\
1906 & 1 & April & 1 & 0 \\
1907 & 3 & February, April, October & 2 & 1 \\
\hline
\end{tabular}

several families residing on a farm near the source of the supply, but at no tlme have cases of typhold occurred among them. These and other considerations anggested that the source of the infection was possibly to be found among the patients themselves, and in the light on recent German work on the occurrence of typhoid carriers, one of us (A. L.) proceeded to investigate the whole question from this point of view. As three-fourths of the cases had occurred among the female Inmates, his attention was confined solely to these. In February of this year a atart was made by testing the Widal reaction in a group of 43 female patients. The serum of 6 cases, 2 of whom had had typhold fever previously (in 1903 and 1904 respectively) gave a well-marked reaction. In the course of this investigation, however, $A . L$. himself contracted an attack of typhoid fever, and nothing further was done in the matter till September, when it was determined to make an exhaustive bacteriological examination of the stools of all the female patlents in the asplum. The samples were forwarded to one of us (J. C. G. L.) at the Lister Institute, London.

\section{Bacieriological Investigation.}

The samples were recelved in sterile bottles, great care being taken to avold any admixture of urine, as the lattex markedly inhibits the growth of intestinal organisms on the plates. From each sample two separate loops were taken and emalsified in two broth tabes. Two plates of bile ealt lactose-nt utral-red agar (MacConkey's medium) were spread with a loopful from each broth tube, four plates in all bing prepared from each sample of laeces.

On the following day the colourless colonies were picked off and inoculated in mannite-peptone water. If gas production occurre $d$ (as in the great majority of the cases) no further consideration was necessary. Where acld production only occurred, a further series of sugar tubes were inoculated (glucose, lactose, cane sugar, and dulcite), also litmus, milk, and gelatine. Indol was tested for by Ehrlich's method on the third day. Agglutination tests were made with an antityphoid horse serum, also with serum from positive cases of typhold fever.

From the main asylum fifty seven samples of faeces from female patients were examined. One patient, $G$. was found to be passing typhold bacllil in enormous numbers in the faeces. In fact, the plates contained typhold colonies to the almost complete exclusion of $B$. coli and other lactose fermenters. This patient, $G$. has been in the asylum since 1896. She is 35 years of gge, suffers from dementia, and there is no record of her having had typhoid fever. Her personal habits are exceedingly filthy, and she has never been employed in the lanndry or kitchen. Her serum agglutinated the Bacillus typhosus up to 1 in 200. (Time, $1 \frac{1}{2}$ hours at room temperature.) 
For this test the laboratory strain was employed Ouriously enough, her own strain was agglutinated very slowly by G.'s serum, but was agglutinated by antityphoid horse serum in dilution of 1 in 8,000 . The $G$. strain had also considerable virulence for the guinespig; 2 c.cm. of a twelve-hour bouillon culture inoculated intraperitoneally caused death withln twenty-four hours.

The patient G. was isolated on September 24th and treated with intestinal antiseptics. On October 12th samples of faeces and urine of G. were recelved. Typhoid bacilli were not found in either. On October 21st the $B$. typhosus was readily isolated from the faeces, and a fourth sample recelved on November 29 th was also positive. The urine remained negative.

With the isolation of $G_{0}$, it was hoped that no more cases of typhoid fever would recur, but this did not prove to be the case. Towards the end of October a case of typhold fever occurred in the small asylum, and accordingly we proceeded to examine the faeces of all the female patients aystematically (34 in number). Another carrier was thus brought to light. This patient, M C., Is about 60 years old. She had an attack of typhold fever in 1895, and has been continuously in the small asylum since that time. She is able to walk about and do a little work, but she has never been employed in the kitchen. Her hablts are cleanly, and she has occasionally assisted in the laundry. It has to be noted that though there are two separate blocks, they are really one, from the extent of communication that goes on between them. The dinners are cooked at the main asylum and brought over to the amaller block. The clothes are washed also at the main asplum, but patients from the small asylum would occasionally assist. As in G.'s case, the plates of M'C. showed almost pure typhoid to the exclusion of lactose fermenters.

The strain obtained from MC. was agglntinated by antityphoid serum in dilution of 1 in 7,000 . The serum agglutinated the laboratory strain, her own strain, and the G. strain up to 1 in 200. The M:C. strain had also the same degree of virulence-for the guinea-pig as the G strain. On November 29th, the Bacillus typhosus was again isolated from the stools of $M^{\prime} C$. but not from the urine.

Bo far the blood has not been examined for typhoid bacilli in either $G$. or $M^{\prime} \cdot C$.

All the females in both buildings had now been gone over, but it was felt advisable to repeat the examination in some of them, especially those who had suffered from typhoid fever in recent years.

A third carrier negative on the previous occasion was thus revealed.

This patient, C., ls about 30 years old and had typhoid fever in 1904. She is not of dirty habits, and has never been employed in kitchen or laundry. The plates pre pared from C. showed very few colonies, and in this respect differed from those of $G$. and $M^{\prime} C$. The serum gives a marked Widal reaction, and the strain obtained from the atools is agglutinated by antityphold serum in dilution of 1 in 7,000 .

Up to the present time, therefore, we have succeeded in isolating three typhold carriers out of a total of ninety females examined. The male patients have so far not been investigated, but we are at present considering this step.

Prophylactic Measures.

We shall conclude with come observations as to the treatment adopted in these cases. In addition to isolation and disinfection of excreta, so-called intestinal and urinary antiseptics have been employed in our cases, but it is not at all likely that they will do the slightest good. Other workers have recorded quite negative results with milk diet, chloroform, hepatic cholagogues, sslol, etc.

It seems probable that in these cases the bacill vegetate in the gall bladder, from which they are intermittently ejected into the intestine. An interesting case, showing the importance of the gall bladder as the seat of vegetation of the Bacillus typhosus, is recorded by Levy and Kayser (1907). A female asylum patient who had been isolated as a typhoid carrier on October 17th, 1905, died on October 18th, 1906, after a short 1llness, in which fever, pulmonary trouble, and stupor were marked symptoms. At the necropsy, hy postatic pneumonia was found, the spleen was slightly enlarged, and a gall stone was present in the fundus of the gall bladder. Typhold bacilli were isolated Irom the liver, opleen, bile, gall bladder wall, and interior of gall stone. In view of the general distribution of the typhoid bacillus in this case, the anthors conclude that death was due to an antolnfection from the gall bladder where the bacillus had 80 far led a saprophytic existence.

Dehler (1907) has actually performed cholecystostomy and drainage of the gall bladder in two asylum carrier cases, though in neither were there symptoms pointing to gall-bladder discase.

Numerons examinations of the stools were made after the operatione, and it was found that in a few months the typhoid bacllil ceased to appear in the faeces, and the patient's serum failed to agglutinate the typhold bacillus.

It cannot, however, be expected that this form of treatment will become popular, at least where otherwlse healthy carriexs are concerned.

The appropriate treatment of these cases presents many difficulties, but one conclusion is clear-that a person who is found to be a ty phoid carrier should be kept constantly under bacteriological supervision. Perhaps also many typhold epldemics would be avolded if the excrets of recovered typhold cases (especially temale cases) were examined aystematically (say once a month) up to six months after recovery.

1906. Kayser (1): Ueber die Gefährlichkeit der Typhusbazillenträger. Arb.a. d. kais, Gesundh., Bd 24, p. 176.

1906. Kayser (2): Milch u. Typhusbazillenträger. Arb. a. d. kais. Gesundh., Bd. 24, p. 173.

T. Kayser (3) : Ueber Untersuchungen bel Personen die vor Jahren "

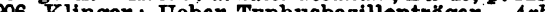

Bd. 24, p. 91 . 1906. Nieter $u$. Liefmann: Ueber bemerkenswerte Befunde bes Untersuchungen auf das Vorhandensein von Typhusbazillenträgern in einer Irrenanstalt. Munch. med. Woch. p. 1611

1907. Nieter: Ueber das Vorkommen und die Bedeutung von Typhusbazillenträgern in Irrenanstalten. Mïnch. med. Woch., p. 1622.

. Levy u. Kayser . Bakteriologischer Befund bei der Autopsie eines Typhusbazillenträgers. Münch. med. Woch., p. 2434. Also, Arb. a. d. 1907.

Typhusträger. Zeitsch, für, Med,Beamte, No.

ar : Zur Behandlung der Typhusbazillenträger. Münch. med. Woch., No. 16 and No. 43.

Chronic Typhoid Germ Distributor. Jourm. Amer. Med. A880c., vol. xlvili, p. 2019.

THE CONTENTS OF IRREDUCIBLE INGUINAL. HERNIAE IN FEMALE' SUBJECTS, AND TRUE HERMAPHRODITISM.

BY EDRED M. CORNER, M.C.CANTAB., F.R.C.8.ENG, SURGEON IN CHARGE OF OUT-PATIENTS TO AT. THOMAS'S HOSPITAI AND TO THE CHILDREN'S HOSPITAI, GREAT ORMOND STREET, ETC.

Trere is a condition of inguinal hernis found in females which deserves much more attention than has hitherto. keen given to it. It is concerned with the irreducibllity of the hernia, and differs in a most marked manner when found in aduits from that when found in children. This condition is the presence of some of the female internal genitalia in the hernla sac. In order to arrive at extensive information on the subject, I aoked Mr. 8. G. Allen, F.R C.S., of the Childrtn's Hospital, Great Ormond Street, to obtain for me some figures of the irreduclble herniae in female patients admitted at that Institution. He looked through 11800 cases, and amongst them found 103;90 were reducible, 4 were irreducible, and 9 were strangulated. Of the latter 13, the contents of the hernis were recorded, every one containing some of the interna genitalis of the female. The uniformity of the condition in them is most striking.

To contrast with this, Mr. L. E. C. Norbury, F.R.O.8., Surgical Registrar to St. Thomas's Hospltal, made for me a list of the irreducible inguinal herniae of femsle patients admitted to the hospital. Since 1878, 52 such cases have been admitted and operated upon. Ot these 52, 3 were children, and have been added to the 13 of Great Ormond Street, bringing the total up to 16. These two groops of hospital cases, chlldren and adults, possess distinctive features as regards the age of the subject and the contents of the hernis.

Class 1.-All were infants, the joungest being 9 weeks and the oldest 13 months.

Class 2.-All were adults, the youngest being 15 and the oldest 19. The generality of the patients were between 40 and 50 . 